\title{
DESENVOLVIMENTO DA TÉCNICA DE SEMI-NESTED-RT-PCR PARA A DETECÇÃO \\ DO VIRUS DA DOENÇA DE NEWCASTLE EM POMBOS CAPTURADOS EM \\ JABOTICABAL-SP, BRASIL
}

\author{
(DEVELOPMENT OF SEMI-NESTED-RT-PCR FOR THE DETECTION OF NEWCASTLE DISEASE \\ VIRUS IN PIGEONS CAPTURED IN JABOTICABAL-SP, BRAZIL)
}

\section{E. S. OLIVEIRA ${ }^{1 *}$, F. S. FERNANDO ${ }^{2}$, K. R. SILVA ${ }^{3}$, R. M. SANTOS ${ }^{4}$, M. F. S. MONTASSIER $^{5}$, H. J. MONTASSIER ${ }^{6}$}

O vírus da doença de Newcastle (VDN) é o agente causador de uma das mais importantes doenças de aves domésticas e silvestres e representa uma ameaça para a avicultura. Os pombos (Columba livia) são susceptíveis ao VDN, sendo considerados disseminadores em potencial desse vírus e por esse motivo tem um importante papel na cadeia epidemiológica dessa enfermidade que é capaz de causar impactos econômicos negativos para a indústria avícola. Este estudo teve por objetivo investigar a presença do VDN em suabes cloacais de 101 pombos capturados em Jaboticabal-SP, com base na técnica molecular Semi-nested-RT-PCR, tendo como alvo a amplificação da região codificadora da proteína de Fusão de 196 pb. Foram avaliadas quatro combinações de primers externos com os internos na técnica de Semi-Nested-RT-PCR, testando-as em diluições seriadas de amostras de líquido córion-alantóide (LCA) infectado com a estirpe LaSota do VDN. Escolhendo-se a combinação de primers externos e internos que revelou uma maior sensibilidade analítica para ser aplicada na análise dos suabes cloacais de pombos. Os resultados mostraram que a melhor combinação de primers externos e internos apresentou um limiar de detecção na Semi-Nested-RT-PCR até a diluição $10^{-10}$ da suspensão de LCA com VDN. A especificidade analítica dos primers foi também avaliada utilizandose suspensões de LCA infectadas com quatro vírus heterólogos ao VDN, dos quais nenhum produto amplificado foi gerado. Os resultados obtidos mostraram que das 101 amostras de suabes cloacais de pombos analisadas, $9(8,9 \%)$ foram positivas para a presença do VDN. Concluindo, a técnica de Semi - nested - RT - PCR desenvolvida nesse estudo mostrou-se eficiente na detecção específica e com elevada sensibilidade do VDN, tanto em amostras de LCA como de suabes cloacais de pombos, indicando o seu grande potencial de aplicação no diagnóstico direto do VDN em diferentes tipos de amostras biológicas provenientes de aves. 